\title{
Re-Os Isotope Systematics of Oxide Xenocrysts and Peridotite Xenoliths from the Kimberlites and the Argyle Lamproite, Kimberley Block, Australia: Implications for the Evolution of the Continental Lithospheric Mantle
}

Graham, S. ${ }^{~, ~ L a m b e r t, ~ D . D . ~ ', ~ S m i t h, ~ C h r i s . B . ~}{ }^{2}$, Shee, S.R. ${ }^{3}$, and Reeves, S.J. ${ }^{4}$

1 Victorian Institute of Earth and Planetary Sciences, Department of Earth Sciences, Monash University, Clavton, 3168 , Australia

2 Rio Tinto Exploration Pty. Ltd. Bundoora, 3083, Australia

3 Stockdale Prospecting Pty. Ltd. South Yarra, 3141 , Australia

4 Victorian Institute of Earth and Planetary Sciences, Department of Earth Sciences, Melbourne University, Parkville, 3052 , Australia

\section{Introduction}

In order to constrain the age of the continental lithospheric mantle beneath the Kimberley Block we have obtained six low-blank Carius tube Re-Os isotopic analyses for oxide xenocrysts, peridotite xenoliths and diamondiferous rocks from the North and East Kimberley Provinces. Furthermore, to constrain lithospheric mantle enrichment events we have obtained Sm-Nd isotopic data for lamproites and a kimberlite from the West and North Kimberley Provinces respectively.

\section{Regional Geological Setting}

The oldest rocks exposed on the Kimberley Block are approximately $\sim 1900 \mathrm{Ma}$. The block forms part of the 1850 - 1700 Ma North Australian Craton, where Archaean rocks are exposed only within the Pine Creek Inlier, although the Kimberley Block is assumed to contain an Archaean continental lithospheric mantle root. The southern and eastern margins to the Kimberley Block are defined by the 1865-1850 Ma Hooper Orogeny, a subduction orogen which forms the basement to the Halls Creek and King Leopold Orogens. At $\sim 1200 \mathrm{Ma}$, reactivation of Hooper Orogen structural lineaments produced northward thrusting in the King Leopold and Halls Creek Orogens (Myers et al., 1996).

Four major suites of alkaline ultramafic intrusions occur on and near the Kimberley Block (Fig. 1). Emplacement ages range from $\sim 1200 \mathrm{Ma}$ to $\sim 800 \mathrm{Ma}$ for lamproites, melnoites and kimberlites from the East, Central and North Kimberley Provinces. West Kimberley Province lamproites have emplacement ages of $\sim 20 \mathrm{Ma}$.

\section{Geochemical and Isotopic Results}

PGE data for the Seppelt kimberlite, Argyle lamproite and Argyle peridotite xenoliths are compared to on- and off-craton kimberlites from southern Africa (McDonald et al., 1995) in Figure 2. The IPGE are slightly fractionated in both the Seppelt kimberlite and Argyle lamproite compared to on-craton kimberlites, which tend to have a flat pattern similar to the Argyle peridotites. $\mathrm{Pd} / \mathrm{Ir}$ ratios for all the Kimberley samples are low $(0.9-1.8)$ compared to other low degree partial melts (e.g., alkali OIB $\mathrm{Pd} / \mathrm{Ir} \sim 5$; off-craton kimberlites $\mathrm{Pd} / \mathrm{Ir}>10$ ), but similar to onand marginal to craton kimberlites from South Africa. All of the Kimberley whole rock samples, as well as xenocryst chromites from Seppelt, have Re/Os concentration ratios consistent with the mantle restite reservoir (Figure 3). Thus, the $\mathrm{Re}-\mathrm{O}$ s and $\mathrm{Pd} / \mathrm{Ir}$ ratios show that incorporation of lithospheric mantle may control the refractory element budget of kimberlites and lamproites.

Sm-Nd isotopic data for the Seppelt kimberlite, West Kimberley and Argyle lamproites all show evolution of the source in a low Sm/Nd (LREE enriched) environment (Figure 4). Recalculated Nd isotopic data from Jaques et al. (1989) yield an average initial $\varepsilon_{\mathrm{Nd}}$ value of -5.5 and a $\mathrm{T}_{\mathrm{DM}}$ model age of $\sim 1950 \mathrm{Ma}$. Sm-Nd isotopic data from the Seppelt kimberlite yield a radiogenic initial $\varepsilon_{\mathrm{Nd}}$ value with a model age of $\sim 1200 \mathrm{Ma}$. The West Kimberley lamproites yield unradiogenic initial $\varepsilon_{\mathrm{Nd}}$ values with model ages of $\sim 1300 \mathrm{Ma}$. Both West and North Kimberley rocks have radiogenic $1200 \mathrm{Ma} \varepsilon_{\mathrm{Nd}}$ values, showing that it is unlikely that these rocks have the same source as each other or the Argyle lamproite.

The Argyle lamproite has a radiogenic initial Os isotopic composition, a feature commonly observed in igneous rocks derived from Re enriched sources. However, superchondritic Os isotopic compositions coupled with a subchondritic $\mathrm{Re} / \mathrm{Os}$ ratios are impossible via normal magmatic processes. Thus the Re/Os ratio appears to be disturbed in this sample, potentially as a result of alteration. Peridotite xenoliths from the Argyle lamproite have subchondritic Os 
isotopic compositions at lamproite emplacement. These data yield $\mathrm{T}_{\mathrm{RD}}$ model ages which are younger than the accepted lamproite emplacement age. The best continental lithospheric mantle age estimate from Argyle peridotite xenoliths is $2000 \pm 150 \mathrm{Ma}$ (Figure 5). This interpretation is based on $T_{C H U R}$ model age results and assumes the xenoliths have remained isotopically closed during and after emplacement. If the xenoliths have gained $\mathrm{Re}$ during emplacement then the source would be considerably younger than $2000 \mathrm{Ma}$. However, the consistency of xenolith data suggests the $T_{\text {CHUR }}$ model age is accurate, and may represent a maximum estimate.

Xenocryst ilmenites from the Maude Creek kimberlite plot within the mantle melt field in Figure 3. This is in agreement with ilmenite xenocrysts representing the products of melts ultimately derived from the asthenospheric mantle. The $\mathrm{T}_{\mathrm{CHUR}}$ model age of $\sim 1500 \mathrm{Ma}$ is similar to the Argyle diamond formation event (Burgess et al., 1992; Richardson, 1986). The proximity of the Maude Creek kimberlite to the Argyle lamproite may therefore imply metasomatism-melt addition either immediately prior to or contemporaneous with diamond growth.

The Seppelt kimberlite has a low Re/Os concentration ratio with a subchondritic initial Os isotopic composition. The Os isotopic data also yield a $T_{R D}$ model age of $\sim 1000$ Ma (Figure 6). The calculated $T_{C H U R}$ model age for this sample does not intersect the Os isotopic mantle evolution line, probably due to the presence of $\mathrm{Pb}$-sulphides in post emplacement veins which suggest interaction with a crustal fluid and Re or radiogenic Os addition. Xenocryst chromites from the kimberlite have a subchondritic $\mathrm{Re} / \mathrm{Os}$ concentration ratio and initial Os isotopic composition. $\mathrm{T}_{\mathrm{RD}}$ and $\mathrm{T}_{\mathrm{CHUR}}$ model ages for the chromites are $1400 \pm 150 \mathrm{Ma}$ and $2200 \pm 200$ $\mathrm{Ma}$, respectively.

\section{Conclusions}

The Sm-Nd isotopic data may preclude melting of the same source in the genesis of all studied rocks. West and North Kimberley Province rocks have radiogenic $\varepsilon_{\mathrm{Nd}}$ values at $1200 \mathrm{Ma}$, inconsistent with the evolved isotopic data from Argyle lamproite dykes at $1200 \mathrm{Ma}$. Importantly, the lamproite Sm-Nd $\mathrm{T}_{\mathrm{DM}}$ and peridotite Re-Os $\mathrm{T}_{\mathrm{CHUR}}$ model ages are internally consistent $(2000 \mathrm{Ma})$. The isotopic data therefore suggest that the Argyle lamproite and peridotite xenolith sources were formed during the Hooper Orogeny. These results clearly show the complexity and multi-stage isotopic history of the continental lithospheric mantle source(s) of alkaline ultramafic magmatism. We believe that our Re-Os data from Seppelt chromite xenocrysts provide the best Kimberley Block lithospheric mantle age estimate, i.e. $2200 \pm 200 \mathrm{Ma}$.

The superchondritic Os evolution of the Maude Creek xenocryst ilmenites and the $1500 \mathrm{Ma}$ $\mathrm{T}_{\text {CHUR }}$ model age suggest that ilmenite crystallisation can precede or coincide with diamond growth. The data presented in this study are new and significant. The application of Re-Os isotopes may place some important constraints on mantle conditions for diamond growth and lead to the development of regional lithospheric mantle maps which may discriminate potential "mantle root friendly" from "mantle root destructive" regions based on xenocryst Re-Os isotopic compositions.

\section{References}

Burgess, R., Turner, G., and Harris, J.W., 1992, ${ }^{40} \mathrm{Ar}-{ }^{39} \mathrm{Ar}$ laser probe studies of clinopyroxene inclusions in eclogitic diamonds: Geochim. Cosmochim. Acta, 56, p. 389-402.

Jaques, A.L., Sun, S-S., and Chappell, B.W., 1989, Geochemistry of the Argyle (AK1) lamproite pipe, Western Australia: In Ross et al. (eds) Volume 1, G.S.A. Special Publication 14, p. 170188.

Jaques, A.L., O’Neill, H.St.C., Smith, C.B., Moon, J., and Chappell, B.W., 1990, Diamondiferous peridotite xenoliths from the Argyle (AK1) lamproite pipe, Western Australia: Cont. Min. Petrol., 104, p. 255-276.

McDonald, I., de Wit, M.J., Smith, C.B., Bizzi, L.A., and Viljoen, K.S., 1995, The geochemistry of the platinum-group elements in Brazilian and southern African kimberlites: Geochim. Cosmochim. Acta, 59, p. 2883-2903.

Myers, J.S., Shaw, R.D., and Tyler, I.M., 1996, Tectonic evolution of Proterozoic Australia: Tectonics, 15, p. 1431-1446. Richardson, S.H., 1986, Latter-day origin of diamonds of eclogitic paragenesis: Nature, 322, p.
198-202. 
Figure 1 Kimberley Block Geology

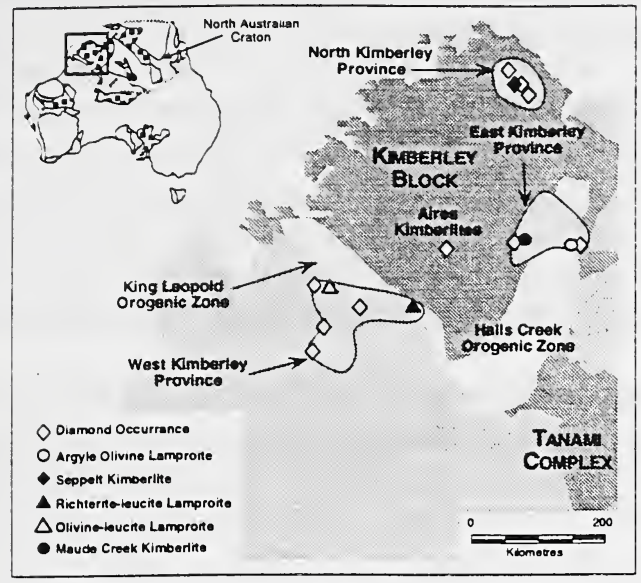

Figure 3. Re-Os Mantle Array

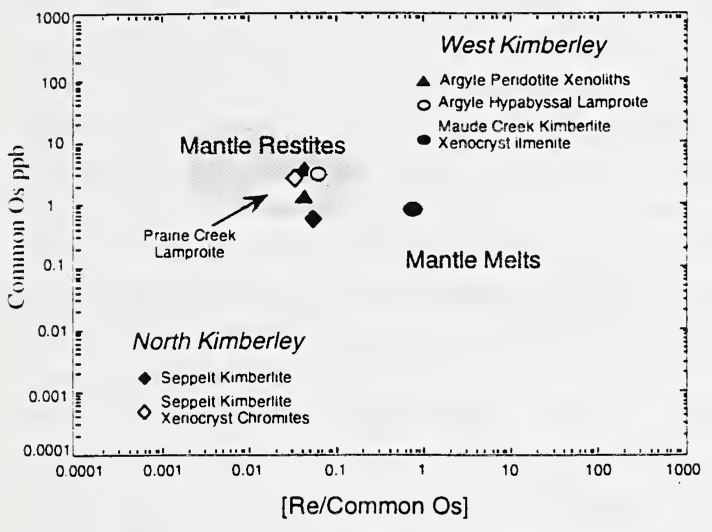

Figure 5. West Kimberley Os Evolution

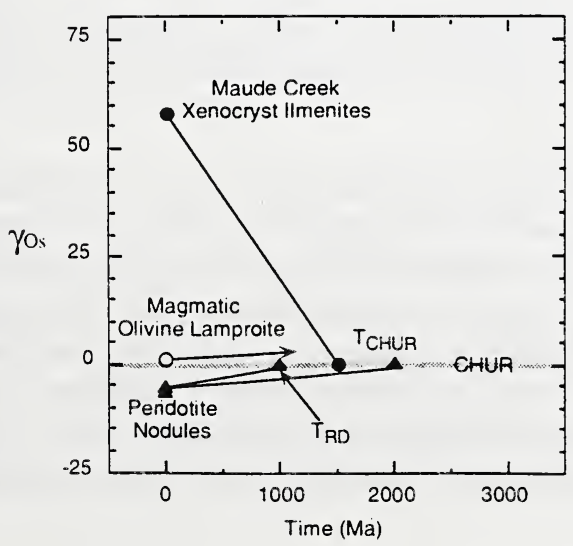

Figure 2. PGE Abundances

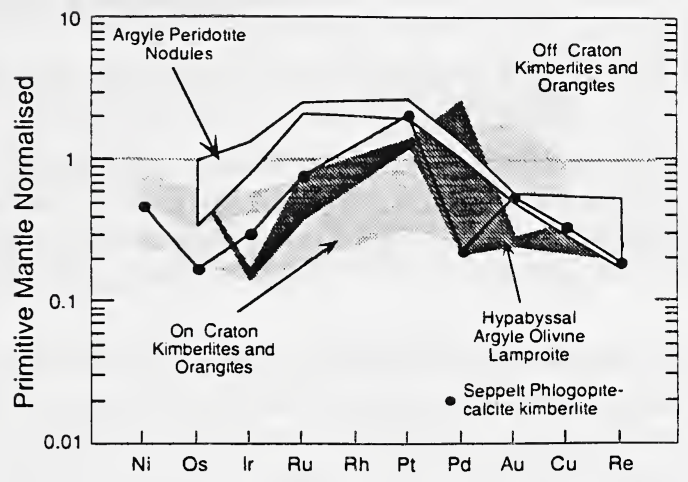

Figure 4. Nd Isotopic Evolution

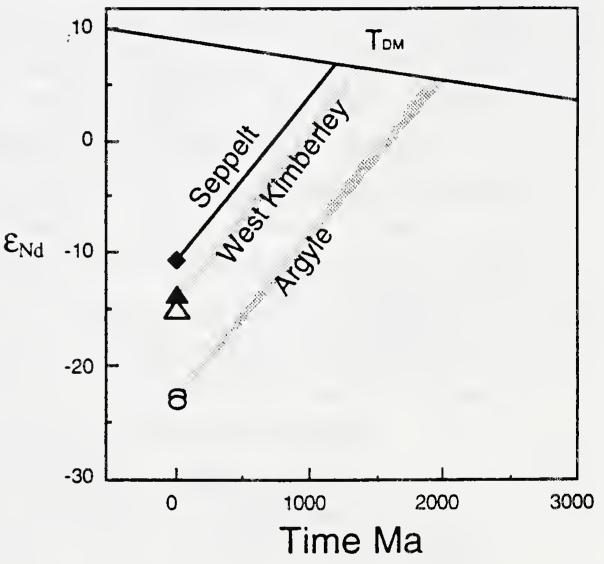

Figure 6. North Kimberley Os Evolution

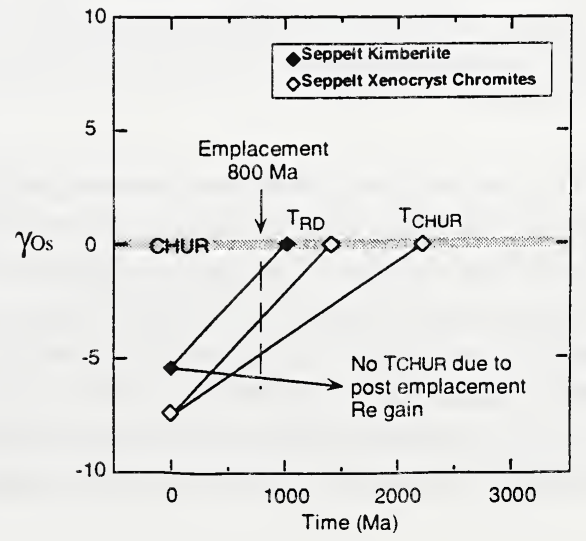

